\title{
I Am a Multitude
}

Walt Whitman has written, "Do I contradict myself? Very well, I contradict myself. I am very large. I contain multitudes." 1

One of the most powerful insights of quantum physics is that we live in a world of multiple potentiality. Nothing is just simply what we see before us now. The quantum wave function (described mathematically in Schrodinger's wave equation) is a superposition of multiple potential "realities"-for instance, photons being both particle-like and wave-like at the same time, both now and then at the same time. Which of these potentialities then gets "real-ized" at our level of reality depends upon how the scientist observes (measures) the wave function with his experimental apparatus. This is the grounds for the quantum insight that everything is "contextual"-a thing always is what it is in relationship to its environment.

For organizations, we saw how a more full realization of all, or at least more, of a company's ways to access the many potentialities in the market is facilitated by the RenDanheyi structure of having multiple teams or microenterprises, each tapping into a different customer base with a different product or service, or using the many skills of its employees in different ways. But this same opportunity is available to each of us in our personal lives. And it is one way of getting Zero Distance between our

${ }^{1}$ Walt Whitman, Song of Myself, No. 51.

(C) The Author(s) 2022

D. Zohar, Zero Distance, https://doi.org/10.1007/978-981-16-7849-3_9 
working lives and personal lives, making both richer and more effective. A kind of RenDanHeyi for the self.

In his book on Taoism, The Watercourse Way, Alan Watts speaks of "that eternal series of surprises that is myself." ${ }^{2}$ I can illustrate this multiple, contextual nature of the self with an example from my own family. When our daughter was nine years old, my husband and I attended a parents' evening at her school. She had many teachers, and we spoke with her Latin teacher first. He was very discouraging. "I really don't know what to do with Anna," he said. "She constantly disrupts the class with her chatter, her homework is always messy, and she is not polite." But then her English teacher spoke very differently. "Anna always makes such good contributions to our classroom discussions, and her poems are so powerful that I have sent them to the school magazine for publication. I wish all my students were like her!" Different teacher, different child.

We have all had the experience of feeling and behaving differently in different relationships and social situations. This is especially true of the person we seem to be at work and the way that we and others see us at home. And most of us have a tendency to say, "I can really be myself here," in some particular context, falsely believing that we have a "true self" present in only some situations, who then, in other situations, "puts on" the mask of a less true persona when deemed appropriate. We are particularly anxious to reject unwanted or uncomfortable "shadow" sides of ourselves of which we feel we should disapprove, often repressing these so strongly that we become unconscious of them, or at least declaring passionately, "That is not what I am really like!" But in fact, all of these selves are "me," and all of them are equally genuine. Each of us is a multitude, and each of our multiple personalities is in fact present, and having an influence on, any particular situation or relationship we happen to be in at a given time. Like everything else in this quantum world of ours, the quantum self is "both/and," not "either/or."

This both/and nature of the quantum self speaks directly to the question of identity that has become such an issue today in society and international politics. People are feeling that their identity is threatened by an "invasion" of others unlike themselves who move into their neighborhoods or who cross their national borders. The whole populist movement that has swept America and Europe owes much of its existence to a fear

${ }^{2}$ Alan Watts, The Watercourse Way, p. 114. 
that these "others" will destroy our identity. Brexit was a fear in the UK that our national identity was eroded by being "swallowed up" by Europe and European immigrants. The ultranationalism that accompanies this populism is a fear that our national identity is threatened by globalism. We must build walls! We must strengthen our borders! But we have seen from our earlier discussions that, in the entangled quantum reality of our universe, where everything is connected to everything, where the entire universe and everything and everyone in it is inside each one of us, there are no "others." The "other" is simply an unrecognized or split off part of myself. And now we can see from the both/and nature of the quantum self, that multiple, coexisting identities are in fact what each of us is made of. The notion of the human self as a separate, atomistic island onto itself, is now as discredited by science as the old, Newtonian view that the universe is composed of separate, discrete, and impenetrable atoms. Each of us is a multitude.

We can visualize the reality of the multitude that each of us is by looking at a figure inspired by a diagram of "quantum potential" drawn by the physicist David Bohm to illustrate what happens to the wave function of a quantum entity when that entity is observed or measured. The wave function carrying a superposition of multiple potentialities does not "collapse" into just one single reality when observed, as quantum scientists used to believe. Instead, it is now known that the wave function simply "decoheres," or spreads out as a rich and varied spectrum of these once superimposed potentialities. When observed, it becomes an array of various, partially expressed, "sleeping," or wave-like, realities and one fully expressed, particle-like reality that is the object of that particular observation (Fig. 9.1)..$^{3}$

In this diagram, each of the many peaks of energy shown has the potential to be observed as a particle if it is evoked by a different observation, but all of the peaks share the "space" within them as a common, wavelike feature. Though only the highest peak manifests as an observable particle, that particle actually contains within itself the common, wavelike, reality represented by all the peaks. When the scientist measures the one, visible, particle, its broader, and invisible, wave-like aspect is fully "implied within" the one reality being detected. And it is the same with the quantum self. The child that her English teacher praised was present

${ }^{3}$ Paaavo Pylkkaanen, Mind, Matter, and the Implicate Order, p. 167. 


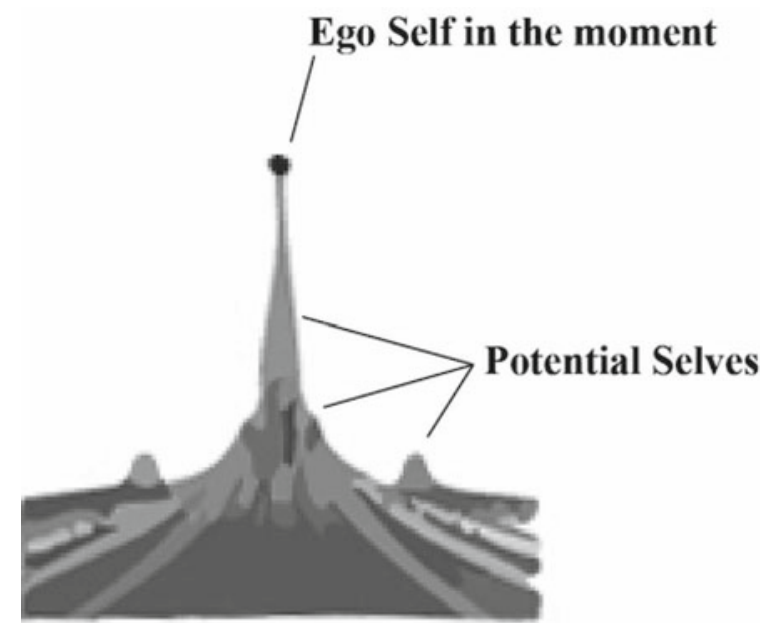

Fig. 9.1 Multiple potentialities of the self

in her Latin classroom, if only the Latin teacher had had the wider sensitivity to sense it, and the skill of a teacher who could evoke it. A skillful leader can do the same for an employee who seems "not up to the job," or for the immigrant who "does not belong here."

We will see in Chapter 14 that the celebration of diversity is one of the twelve principles of quantum leadership. In fact, the celebration of the diversity within each of ourselves is a principle of quantum living. The more numerous the sides of ourselves that we recognize and cultivate, the more fully we become ourselves. The more "strangers" we welcome in our neighborhood, the richer and more vital we and our community become. Even the rejected "shadow" sides of ourselves have a potential to add to the richness of our life experience and to the value we can bring to our relationships. Indeed, the Swiss psychologist Carl Jung believed that much of our creativity is hidden away in the shadow. It is the $y i n$ within the $y$ in/yang self. The shadow sides of ourselves are simply damaged potentialities that were distorted by painful childhood experiences. If we face them, own them, and heal them, they can be integrated into the broader array of our positive sides and qualities and give greater life to all. The employee who functions poorly on one team, in fact has skills and qualities that will add great value to another. 
Zhang Ruimin has said that as an employee creates his/her product, they thereby also create themselves. In the RenDanHeyi management model, every employee adds to their skill set and confidence as they creatively respond to user needs. It is the same in a RenDanHeyi model of the self. Every time we expose ourselves to a new experience or a new idea, every time we stretch ourselves or go outside our comfort zone, every time we see that another's "difference" is actually an unrecognized part of ourselves, we bring forth or strengthen those potential, different sides of ourselves, or evoke new ones, and we become more who we truly are. And when we "introduce" these different "me's" to ourselves and others by bringing more of them into each present situation or relationship, we integrate who we truly are. Such self-creation and self-integration is the essence of possessing integrity, of being "authentic." We are more present to ourselves and others. We feel more "real" to ourselves, and more trustworthy to others. We simply are more.

Open Access This chapter is licensed under the terms of the Creative Commons Attribution-NonCommercial-NoDerivatives 4.0 International License (http:// creativecommons.org/licenses/by-nc-nd/4.0/), which permits any noncommercial use, sharing, distribution and reproduction in any medium or format, as long as you give appropriate credit to the original author(s) and the source, provide a link to the Creative Commons license and indicate if you modified the licensed material. You do not have permission under this license to share adapted material derived from this chapter or parts of it.

The images or other third party material in this chapter are included in the chapter's Creative Commons license, unless indicated otherwise in a credit line to the material. If material is not included in the chapter's Creative Commons license and your intended use is not permitted by statutory regulation or exceeds the permitted use, you will need to obtain permission directly from the copyright holder.

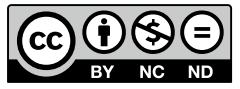

